\title{
Effectiveness and safety of mepolizumab in combination with corticosteroids in patients with eosinophilic granulomatosis with polyangiitis
}

Masanobu Ueno, Ippei Miyagawa, Kazuhisa Nakano, Shigeru Iwata, Kentaro Hanami, Shunsuke Fukuyo, Satoshi Kubo, Yusuke Miyazaki, Akio Kawabe, Hiroko Yoshinari, Shingo Nakayamada and Yoshiya Tanaka* (1)

\begin{abstract}
Background: Mepolizumab (MPZ), an anti-interleukin-5 antibody, is effective for the treatment of eosinophilic granulomatosis with polyangiitis (EGPA). However, its effectiveness has not been adequately evaluated in real-world clinical practice. In this study, we assessed the effectiveness and safety of MPZ (300 mg) for relapsing/refractory EGPA resistant to corticosteroids (CS) for 1 year in real-world settings.

Methods: We administered MPZ (300 mg) to 16 patients with relapsing/refractory EGPA resistant to CS (Post-MPZ). We also retrospectively collected data from the same patients for the 12 months before the administration of MPZ (Pre-MPZ). The primary endpoint was the 12-month remission rate after MPZ administration and the secondary endpoints were the Birmingham vasculitis activity score (BVAS), vasculitis damage index (VDI), eosinophil counts, changes in concomitant CS doses/concomitant immunosuppressant use, MPZ retention rate, and incidence of adverse events. The clinical course was compared between Pre-MPZ and Post-MPZ.

Results: The 12-month remission rate after the initiation of MPZ was 75\%. No change was observed in BVAS, eosinophil count, or concomitant CS dose over time in the Pre-MPZ group, whereas all these parameters were significantly decreased over time in the Post-MPZ group. The number of patients using concomitant immunosuppressant also decreased over time in the Post-MPZ group. VDI did not increase in either group. The MPZ retention rate was 100\% and only three patients (18.8\%) had infections. Changes in BVAS, eosinophil count, and cumulative concomitant CS dose were significantly lower in the Post-MPZ group than in the Pre-MPZ group. There was no significant difference in the changes in VDI between the groups.
\end{abstract}

Conclusion: This study demonstrated that MPZ is effective and safe for EGPA. Furthermore, MPZ decreases disease activity, increases remission rate, and has a CS-sparing effect.

Keywords: Eosinophilic granulomatosis with polyangiitis, Corticosteroid, Mepolizumab, Treatment

\footnotetext{
* Correspondence: tanaka@med.uoeh-u.ac.jp

The First Department of Internal Medicine, School of Medicine, University of Occupational and Environmental Health, Japan, 1-1 Iseigaoka, Kitakyushu 807-8555, Japan
}

(c) The Author(s). 2021 Open Access This article is licensed under a Creative Commons Attribution 4.0 International License, which permits use, sharing, adaptation, distribution and reproduction in any medium or format, as long as you give appropriate credit to the original author(s) and the source, provide a link to the Creative Commons licence, and indicate if changes were made. The images or other third party material in this article are included in the article's Creative Commons licence, unless indicated otherwise in a credit line to the material. If material is not included in the article's Creative Commons licence and your intended use is not permitted by statutory regulation or exceeds the permitted use, you will need to obtain permission directly from the copyright holder. To view a copy of this licence, visit http://creativecommons.org/licenses/by/4.0/. The Creative Commons Public Domain Dedication waiver (http://creativecommons.org/publicdomain/zero/1.0/) applies to the data made available in this article, unless otherwise stated in a credit line to the data. 


\section{Key messages}

MPZ is safe for the treatment of EGPA in real-world clinical practice.

Comparing to Pre-MPZ, MPZ possesses the high remission rate and CS sparing effect.

\section{Background}

Eosinophilic granulomatosis with polyangiitis (EGPA) is a disease that is preceded by asthma or allergic rhinitis. EGPA causes various symptoms owing to vasculitis, including fever and purpura, and increases peripheral eosinophil counts $[1,2]$. Corticosteroids (CS) are used in remission induction therapy and maintenance therapy for EGPA. Patients with severe vasculitis symptoms and those who respond poorly to CS are treated with cyclophosphamide (CY), azathioprine (AZ), methotrexate (MTX), cyclosporine (CsA)/tacrolimus (TAC), or intravenous immunoglobulin (IVIG). However, EGPA often relapses during CS dose reduction; hence, CS dose reduction is often challenging [3-5].

In recent years, mepolizumab (MPZ), an antiinterleukin-5 (IL-5) monoclonal antibody, has been reported to extend the remission period of EGPA and reduce the CS dose required [6]. Although MPZ was listed in the National Health Insurance drug price list for the treatment of EGPA in Japan in 2018, its effectiveness and safety have not been adequately evaluated in realworld clinical practice. Although the dose of MPZ administered in previous studies was $100 \mathrm{mg} /$ month, which is the same dose used for the treatment of bronchial asthma, an MPZ dose of $300 \mathrm{mg}$ is used in some countries, including Japan. Thus, we investigated the effectiveness and safety of MPZ at a dose of $300 \mathrm{mg} /$ month in a real-world setting.

\section{Methods}

\section{Patients}

In this study, MPZ (300 mg) was administered to $16 \mathrm{pa}-$ tients with relapsing or refractory EGPA who were receiving the standard of care, mainly CS $[7,8]$. In Japan, the use of MPZ is allowed when the effect of CS therapy is insufficient. All patients used in this study met this criterion. All patients were diagnosed with EGPA according to the diagnostic criteria for EGPA, as proposed by the Japanese Ministry of Health, Labour and Welfare, and met the classification criteria of the American College of Rheumatology [9] (Table 1, Supplementary Table 1). Patients in remission and those with relapsing or refractory EGPA were defined as follows according to the criteria of the Mepolizumab Treatment in Relapsing or Refractory EGPA trial [6]: patients with remission had a Birmingham vasculitis activity score (BVAS) of 0 and were treated with oral CS at a dose of $\leq 4 \mathrm{mg} /$ day; patients with relapsing EGPA had an increased oral CS dose, started concomitant immunosuppressive therapy, had an increased concomitant immunosuppressant dose, had an increased BVAS [10], or had a history of hospitalization; and patients with refractory EGPA experienced no relapse and achieved no remission within the last 1 year.

The patients were followed up for 12 months after the introduction of MPZ at our hospital and affiliated institutions, during the period between the domestic introduction of MPZ in May 2018 until August 2020 (PostMPZ). Additionally, we retrospectively collected data from the same patients for the 12 months before the initiation of MPZ therapy (Pre-MPZ). All patients received maintenance therapy according to the standard of care. The standard of care in this study was defined as treatment with CS, intravenous CY, intravenous immunoglobulin, azathioprine, MTX, or CsA/TAC. The Human Ethics Review Committee of our university reviewed and approved this study (No. H27-014). We also complied with the Declaration of Helsinki. All participants provided informed consent prior to inclusion in the study. Details that might disclose the identity of the study subjects were omitted.

\section{Clinical measurement}

This study was a multicenter and ambispective cohort study in which MPZ at a dose of $300 \mathrm{mg} / \mathrm{month}$ was administered to 16 patients with relapsing or refractory EGPA to investigate the effectiveness and safety of MPZ over 1 year.

The primary endpoint was the remission rate. The secondary endpoints were the BVAS (overall and for each item), vasculitis damage index (VDI) (overall and for each item) [11, 12], eosinophil counts, daily and cumulative concomitant CS doses, presence or absence of changes/ addition of immunosuppressant(s), MPZ retention rate, and incidence of adverse events. Additionally, the reduction in BVAS, change in VDI, reduction in peripheral eosinophil counts, and cumulative concomitant CS doses were compared between the 1-year period before the initiation of MPZ therapy (Pre-MPZ; month -12 to month 0 ) and 1-year period after the initiation of MPZ (Post-MPZ; month 0 to month 12). To express the results of the two groups synchronously, the original timeframes Pre-MPZ (-12 (baseline), $-11,-9$, and -6 months) are represented as 0 (baseline), 1, 3, and 6 months, respectively.

\section{Measurement of serum concentration of IL-5}

The serum concentration of IL- 5 at the baseline (before MPZ initiation) was measured using the enzyme-linked immunosorbent assay (ELISA) (R\&D SYSTEMS Human IL-5 Duo Set ELISA, P249454) and compared with that of six age- and sex-matched healthy controls. 
Table 1 Baseline characteristic of 16 patients with eosinophilic granulomatosis with polyangiitis

\begin{tabular}{|c|c|c|c|}
\hline & Pre-MPZ $(n=16)$ & Post-MPZ $(n=16)$ & value $^{P}$ \\
\hline $\begin{array}{l}\text { Clinical manifestations at } \\
\text { diagnosis, } n(\%)\end{array}$ & \multicolumn{2}{|c|}{$\begin{array}{l}\text { Asthma } 16 \text { (100), general } 10 \text { (62.5), cutaneous } 8 \text { (50.0), ENT } 5(31.3) \text {, chest } 8 \text { (50.0), cardiomyopathy } 3 \text { (18.8), } \\
\text { abdominal } 1 \text { (6.3), neuropathy } 8 \text { (50.0), ANCA positive status } 5 \text { (31.3), biopsy findings } 12 \text { (75) }\end{array}$} & \\
\hline $\begin{array}{l}\text { Male/female/age at MPZ } \\
\text { introduction }\end{array}$ & \multicolumn{2}{|l|}{$7 / 9 / 61.5[53.3-70.5]$} & \\
\hline $\begin{array}{l}\text { Disease duration (months) } \\
\text { at MPZ introduction }\end{array}$ & \multicolumn{2}{|l|}{$54[22-144]$} & \\
\hline Treatment history, $n(\%)$ & \multicolumn{2}{|c|}{$\begin{array}{l}\text { CS pulse } 2 \text { (12.5), high-dose CS } 14 \text { (87.5), low-dose CS } 2 \text { (12.5), IVCY } 9 \text { (56.3), IVIG } 6 \text { (37.5), RTX } 1 \text { (6.3), MTX } 6 \\
\text { (37.5), AZ } 12 \text { (75.0), TAC } 1 \text { (6.3) }\end{array}$} & \\
\hline $\begin{array}{l}\text { Relapsing/refractory/ } \\
\text { remission, } n(\%)\end{array}$ & $4(25.0) / 11(68.7) / 1(6.3)$ & $10(62.5) / 6(37.5) / 0(0)$ & ND \\
\hline $\begin{array}{l}\text { Concomitant CS dose (PSL } \\
\text { mg/day) }\end{array}$ & $8.0[5.0-11.5]$ & $6.5[2.6-10.0]$ & 0.2012 \\
\hline $\begin{array}{l}\text { Concomitant CS }<4 \mathrm{mg} / \\
\text { day (PSL), } n(\%)\end{array}$ & $3(18.8)$ & $5(31.3)$ & 0.1573 \\
\hline $\begin{array}{l}\text { Concomitant } \\
\text { immunosuppressant, } n(\%)\end{array}$ & AZ 6 (37.5), MTX 5 (31.3), TAC 1 (6.3) & AZ 6 (37.5), MTX 4 (25.0), TAC 1 (6.3) & \\
\hline $\begin{array}{l}\text { Without } \\
\text { immunosuppressant, } n(\%)\end{array}$ & $6(37.5)$ & $7(43.8)$ & 0.3173 \\
\hline BVAS & $0[0-2.0]$ & $1.0[0-3.8]$ & 0.1084 \\
\hline BVAS > $0, n(\%)$ & $4(25.0)$ & $8(50.0)$ & 0.3173 \\
\hline BVAS items & Asthma 2 (12.5), sinonasal $2(12.5)$, chest 1 (6.3) & $\begin{array}{l}\text { Asthma } 6 \text { (37.5), general } 1(6.3) \text {, cutaneous } 2 \text { (12.5), } \\
\text { sinonasal } 2 \text { (12.5), chest } 3(18.8) \text {, }\end{array}$ & \\
\hline VDI & $3.5[3.0-4.8]$ & $4.0[3.0-5.8]$ & 0.5577 \\
\hline VDI items & $\begin{array}{l}\text { Chronic bronchial asthma } 16 \text { (100), chronic respiratory } \\
\text { failure } 1 \text { (6.3), abnormal respiratory function } 7 \text { ( } 43.8) \text {, } \\
\text { old myocardial infarction } 2(12.5) \text {, cardiomyopathy } 2 \\
\text { (12.5), low vision } 1 \text { (6.3), chronic sinusitis } 6 \text { ( } 37.5) \text {, } \\
\text { deafness } 3(18.8) \text {, peripheral neuropathy } 8 \text { (50.0), } \\
\text { diabetes } 4 \text { (25), hypertension } 4 \text { (25), osteoporosis } 5 \\
\text { (31.3), other } 3 \text { (18.8) }\end{array}$ & $\begin{array}{l}\text { Chronic bronchial asthma } 16 \text { (100), chronic respiratory } \\
\text { failure } 1 \text { (6.3), abnormal respiratory function } 8 \text { (50.0), } \\
\text { old myocardial infarction } 2(12.5) \text {, cardiomyopathy } 2 \\
\text { (12.5), low vision } 1 \text { (6.3), chronic sinusitis } 7 \text { (43.8), } \\
\text { deafness } 3(18.8) \text {, peripheral neuropathy } 8 \text { (50.0), } \\
\text { diabetes } 4 \text { (25), hypertension } 4 \text { (25), osteoporosis } 5 \\
\text { (31.3), other } 5 \text { (31.3) }\end{array}$ & \\
\hline ANCA-positive status, $n(\%)$ & $0(0)$ & $1(6.3)$ & ND \\
\hline $\begin{array}{l}\text { Absolute eosinophil count } \\
(/ \mu \mathrm{L})\end{array}$ & $178.6[48.7-370.2]$ & $183[60.0-2479]$ & 0.1591 \\
\hline CRP $(\mathrm{mg} / \mathrm{dL})$ & $0.06[0.03-0.09]$ & $0.09[0.05-0.24]$ & 0.0593 \\
\hline
\end{tabular}

\section{Statistical analysis}

Data are expressed as the median (interquartile range). For statistical analysis, data from cases in which MPZ was discontinued or the disease relapsed were complemented using the last observation carried forward method. Differences between groups (Post-MPZ vs. PreMPZ) and between data measured at the baseline and each observation point (Post-MPZ: month 0 vs. month $1,3,6,12)$ were compared using the Wilcoxon signedrank test or McNemar test. Differences in the serum IL5 concentration between the patients and healthy controls were compared using the Mann-Whitney $U$ test.

The timeframes of both groups were represented synchronously and compared [- 12 months (baseline) in the Pre-MPZ corresponded to 0 months (baseline) in the
Post-MPZ group]. All reported $P$ values are two-sided. Remission was defined as a BVAS score of 0 and CS less than $4 \mathrm{mg} /$ day. All analyses were conducted using JMP version 14.0.0 (SAS Institute Inc.). The post hoc power of this study for the comparison between month 0 and the other observation points in the Post-MPZ group was 0.37 for BVAS, 0.99 for VDI, 0.36 for absolute eosinophil count, and 0.76 for concomitant CS dose ( $\alpha$ error, 0.05; $1-\beta$ error, post hoc power).

\section{Results}

\section{Patient background}

The characteristics of the patients are shown in Table 1. The characteristics of each patient at the time of EGPA diagnosis are shown in Supplementary Table 1 and those 
at the time of MPZ therapy initiation are shown in Supplementary Table 2. At the time of MPZ therapy initiation, the median age [interquartile range] of the 16 patients with EGPA was 61.5 [53.3-70.5] years and the disease duration was 54 [22-144] months. Regarding medical history, all patients were treated with CS. The Pre-MPZ group included four patients with relapsing EGPA, 11 with refractory EGPA, and one in remission, whereas the Post-MPZ group included 10 patients with relapsing EGPA and six with refractory EGPA. No statistically significant differences were observed in the concomitant CS dose or the rate of concomitant immunosuppressant use between the groups. There were also no statistically significant differences in BVAS, VDI, positivity rate for anti-neutrophil cytoplasmic antibody, eosinophil counts, or C-reactive protein level between the groups. The IL-5 concentration before MPZ therapy initiation was 1.88 [0.28-8.95] pg/mL, which was significantly higher than that in the six age- and sex-matched healthy controls $\left(0.027\right.$ [0.003-0.55], $P={ }^{*} 0.0063$ using Mann-Whitney $U$ test; Supplementary Fig. 1).

\section{Effectiveness of MPZ}

The remission rates (the primary endpoint) were 6.3\% (1/16 patients) at month $1,12.5 \%$ (2/16 patients) at month $3,6.3 \%$ (1/16 patients) at month 6 , and $0 \%$ at month 12 in the Pre-MPZ group. The corresponding rates in the Post-MPZ group were $12.5 \%$ (2/16 patients) at month $1,31.3 \%$ (5/16 patients) at month $3,50.0 \%(8 /$ 16 patients) at month 6 , and $75.0 \%$ (12/16 patients) at month 12 . In this group, the remission rate increased at month 12 (Fig. 1a).

In the Pre-MPZ group, the BVASs were $0[0-2.0]$ at month $1,0[0-2.0]$ at month $3,0[0-2.0]$ at month 6 , and $1.0[0-3.8]$ at month 12 . In the Post-MPZ group, the BVASs were $0[0-2.8]$ at month $1,0[0-0]$ at month $3,0[0-0]$ at month 6 , and $0[0-0]$ at month 12 . The BVASs at month 1 and afterward significantly decreased from the BVAS at month 0 (Fig. 1b). The decrease in BVAS during the 1-year period in the Post-MPZ group was $0.5[0-3.5]$, which was significantly higher than that in the Pre-MPZ group (-1.0 [-3.0-0]; Fig. 2a).

Based on the changes in BVASs for each item, respiratory symptoms were exacerbated in the Pre-MPZ group but improved immediately after the initiation of MPZ therapy. The number of patients with symptoms decreased from $11 / 16$ to $2 / 16$ after 1 year of treatment. Ear, nose, and throat symptoms also improved, as the number of patients with these symptoms decreased from 6/16 to 3/16 patients, 1 year after the initiation of MPZ therapy. In contrast, neuropathy did not improve in either the Post-MPZ or Pre-MPZ groups. In the PostMPZ group, no organ dysfunction was exacerbated at month 12 (Table 2).
In the Pre-MPZ group, the VDI scores were 3.5 [3.04.8] at month 1, 4.0 [3.0-5.5] at month 3, 4.0 [3.0-5.5] at month 6, and 4.0 [3.0-5.5] at month 12. In the PostMPZ group, the VDI scores were 4.0 [3.0-5.5] at month $1,4.0$ [3.0-5.5] at month 3, $4.0[3.0-5.5]$ at month 6 , and 4.0 [3.0-5.5] at month 12 , with no significant changes (Fig. 1c). The increase in the VDI score during the 1-year period was $0[0-0.8]$ in the Pre-MPZ and 0 $[0-0]$ in the Post-MPZ groups, with no significant difference between the groups (Fig. 2b).

In the Pre-MPZ group, the eosinophil counts were 280.4 [63.2-426.8]/ $\mu \mathrm{L}$ at month $1,217.8$ [93.3-1354.2]/ $\mu \mathrm{L}$ at month 3 , and $293.9[39.1-880.7] / \mu \mathrm{L}$ at month 6 . In the Post-MPZ group, the eosinophil counts were 54.8 $[10.6-99.8] / \mu \mathrm{L}$ at month $1,25.2[12.8-53.9] / \mu \mathrm{L}$ at

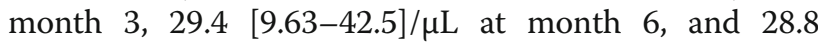
[20.5-68.0] at month 12, with a significant reduction from month 1 onwards (Fig. 1d). The reduction in the eosinophil counts during the 1-year period in the PostMPZ group was 146.2 [9.88-2449.9], which was significantly higher than that in the Pre-MPZ group (- 8.8 [2927.4-175.4]; Fig. 2c).

The changes in the concomitant CS dose in each patient are shown in Table 3. In the Pre-MPZ group, the concomitant CS doses were 8.0 [5.0-10.0] $\mathrm{mg} /$ day at month 1, 7.0 [3.5-10.0] mg/day at month 3, 6.5 [2.6$10.0] \mathrm{mg} /$ day at month 6 , and $6.0[2.6-10.0] \mathrm{mg} /$ day at month 12. In the Post-MPZ group, the concomitant CS doses were $6.5[2.6-10.0] \mathrm{mg} /$ day at month $1,5.0$ [2.3$7.4] \mathrm{mg} /$ day at month $3,4.5[0.5-5.0] \mathrm{mg} /$ day at month 6 , and $2.5[0.1-3.8] \mathrm{mg} /$ day at month 12 , with a significant reduction from month 3 onwards (Fig. 1e). The concomitant CS dose was significantly lower in the PostMPZ group (1655 [570.0-2190.0] mg/year) than in the Pre-MPZ group (2665 [1473.8-3993.8] mg/year; Fig. 2d). The changes in the use of immunosuppressants are shown in Table 4. The number of patients using concomitant immunosuppressant(s) reduced from 10 to nine patients at 1 year in the Pre-MPZ group and from nine to five patients in the Post-MPZ group.

\section{MPZ retention rate and safety}

The 1-year MPZ retention rate was 100\%. Although three patients had an infection, all patients continued MPZ. Adverse events before and after the initiation of MPZ therapy are shown in Table 5. After MPZ therapy initiation, cases 1 and 11 developed bacterial pneumonia that required hospitalization. Sputum culture identified Moraxella catarrhalis in case 1 and Pseudomonas aeruginosa in case 11. In both patients, a drip infusion of antibiotics improved their condition. Case 15 also developed bacterial pneumonia. Because the general and respiratory conditions were favorable, the patient received oral antibiotic therapy at the outpatient clinic and 


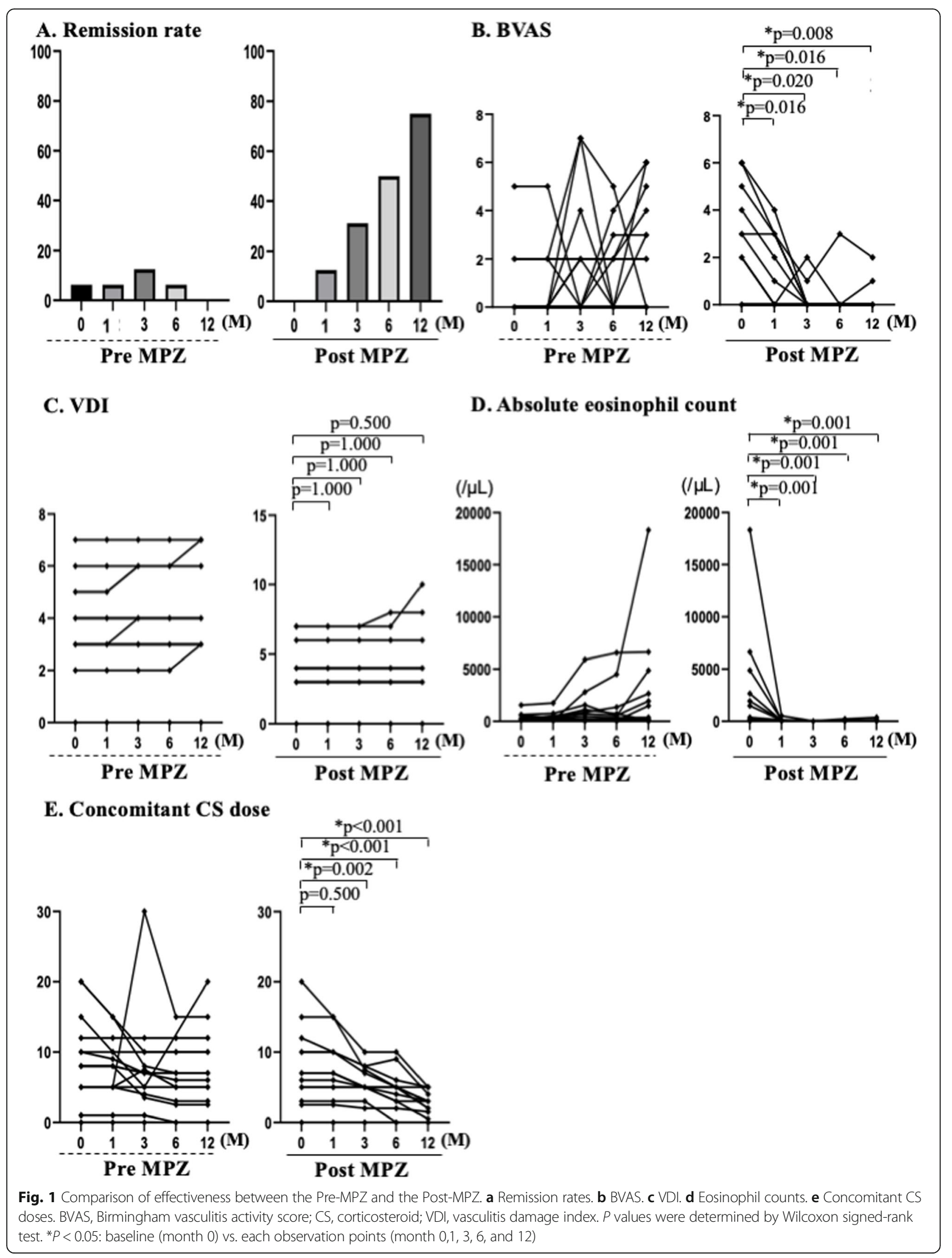




\section{A. Changes in BVAS}

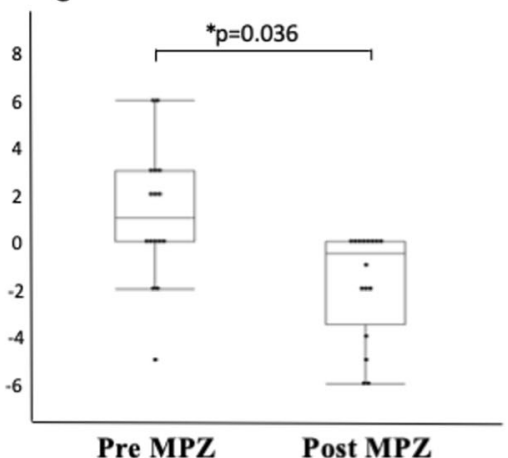

C. Reduction in Absolute eosinophil count

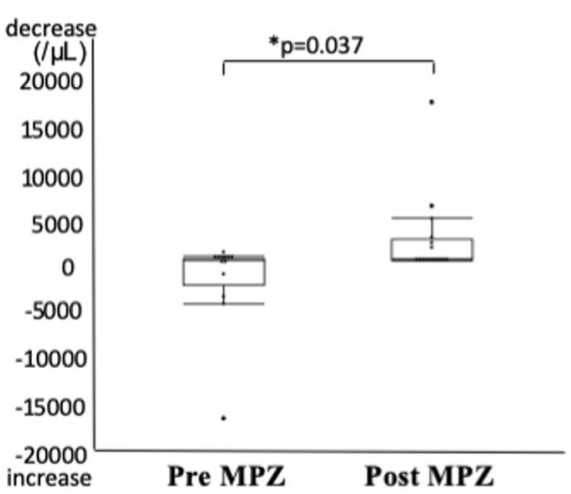

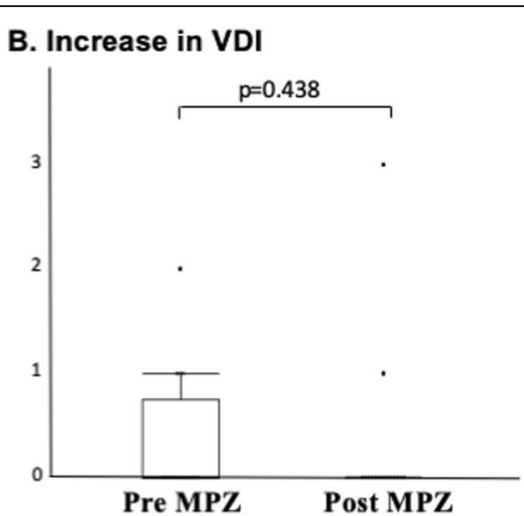

D. Accumulated Concomitant CS dose

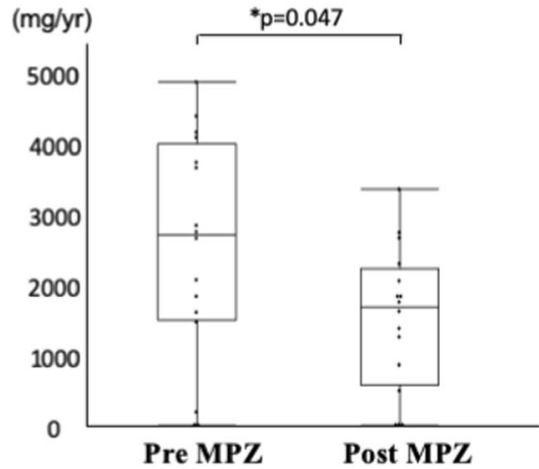

Fig. 2 Comparison of changes of each item between the 12-month period in Pre-MPZ and Post-MPZ. a Changes in BVAS, b increase in VDI, c reduction in peripheral eosinophil counts $(/ \mu \mathrm{L})$, and $\mathbf{d}$ accumulated concomitant CS dose (mg/year). BVAS, Birmingham vasculitis activity score; CS, corticosteroid; VDI, vasculitis damage index. $P$ values were determined by Wilcoxon signed-rank test. ${ }^{*} P<0.05$ : Pre-MPZ vs. Post-MPZ

improved. All three patients who had an infection after the initiation of MPZ therapy had the same infection within 1 year before initiation. None of the patients had a new infection after the initiation of therapy.

\section{Discussion}

The results of this study demonstrated the effectiveness and safety of MPZ for relapsing or refractory EGPA in a real-world setting by comparing the clinical courses before and after the initiation of MPZ therapy. During the 1-year period before MPZ therapy initiation, BVASs increased as CS doses were tapered, although the effectiveness of immunosuppressants in controlling disease activity was inadequate to allow $\mathrm{CS}$ dose reduction. Although many patients used AZ as a concomitant immunosuppressant before MPZ therapy initiation in this study, it has been previously reported that AZ is not useful for maintenance therapy [13]. In this study, BVASs and eosinophil counts significantly decreased 1 month after MPZ therapy initiation. The doses of CS and immunosuppressants were also successfully reduced

Table 2 Changes in organ damage before and after the introduction of MPZ

\begin{tabular}{|c|c|c|c|c|c|c|c|c|c|}
\hline & Pre-MPZ & & & & Post-MPZ & & & & \\
\hline & $-12 M$ & $-11 M$ & $-9 M$ & $-6 M$ & $0 M$ & $1 \mathrm{M}$ & $3 \mathrm{M}$ & $6 M$ & $12 \mathrm{M}$ \\
\hline General symptoms & 0 & 0 & $1(6.3 \%)$ & $1(6.3 \%)$ & $1(6.3 \%)$ & $1(6.3 \%)$ & 0 & $1(6.3 \%)$ & 0 \\
\hline Cutaneous manifestations & $1(6.3 \%)$ & $1(6.3 \%)$ & $1(6.3 \%)$ & $1(6.3 \%)$ & $2(12.5 \%)$ & $2(12.5 \%)$ & 0 & $1(6.3 \%)$ & 0 \\
\hline ENT manifestations & $6(37.5 \%)$ & $6(37.5 \%)$ & $6(37.5 \%)$ & $6(37.5 \%)$ & $6(37.5 \%)$ & $6(37.5 \%)$ & $6(37.5 \%)$ & $4(25.0 \%)$ & $3(18.8 \%)$ \\
\hline Chest manifestations & $6(37.5 \%)$ & $6(37.5 \%)$ & $8(50.0 \%)$ & $8(50.0 \%)$ & $11(68.8 \%)$ & $5(31.3 \%)$ & $2(12.5 \%)$ & $2(12.5 \%)$ & $2(12.5 \%)$ \\
\hline Nervous system manifestations & $7(45.8 \%)$ & $7(45.8 \%)$ & $7(45.8 \%)$ & $8(50.0 \%)$ & $8(50.0 \%)$ & $8(50.0 \%)$ & $7(43.8 \%)$ & $7(43.8 \%)$ & $7(43.8 \%)$ \\
\hline
\end{tabular}


Table 3 Changes in the concomitant corticosteroids use before and after the introduction of MPZ (PSL mg/day)

\begin{tabular}{|c|c|c|c|c|c|c|c|c|c|}
\hline \multirow{2}{*}{$\begin{array}{l}\text { Case } \\
\text { No. }\end{array}$} & \multicolumn{4}{|l|}{ Pre-MPZ } & \multicolumn{5}{|l|}{ Post-MPZ } \\
\hline & -12 months & -11 months & -9 months & -6 months & 0 months & 1 months & 3 months & 6 months & 12 months \\
\hline 1 & $5 \mathrm{mg}$ & $5 \mathrm{mg}$ & $30 \mathrm{mg}$ & $15 \mathrm{mg}$ & $15 \mathrm{mg}$ & 15 mg & 10 mg & $10 \mathrm{mg}$ & $5 \mathrm{mg}$ \\
\hline 2 & $5 \mathrm{mg}$ & $5 \mathrm{mg}$ & $7.5 \mathrm{mg}$ & $5 \mathrm{mg}$ & $5 \mathrm{mg}$ & $5 \mathrm{mg}$ & $5 \mathrm{mg}$ & $5 \mathrm{mg}$ & $5 \mathrm{mg}$ \\
\hline 3 & $8 \mathrm{mg}$ & $8 \mathrm{mg}$ & $3.5 \mathrm{mg}$ & $2.5 \mathrm{mg}$ & $2.5 \mathrm{mg}$ & $2.5 \mathrm{mg}$ & $2 \mathrm{mg}$ & $2 \mathrm{mg}$ & $1.5 \mathrm{mg}$ \\
\hline 4 & $12 \mathrm{mg}$ & $12 \mathrm{mg}$ & $12 \mathrm{mg}$ & $12 \mathrm{mg}$ & $12 \mathrm{mg}$ & $10 \mathrm{mg}$ & $8 \mathrm{mg}$ & $9 \mathrm{mg}$ & $4 \mathrm{mg}$ \\
\hline 5 & $8 \mathrm{mg}$ & $8 \mathrm{mg}$ & $7 \mathrm{mg}$ & $7 \mathrm{mg}$ & $7 \mathrm{mg}$ & $7 \mathrm{mg}$ & $5 \mathrm{mg}$ & $5 \mathrm{mg}$ & $3 \mathrm{mg}$ \\
\hline 6 & $1 \mathrm{mg}$ & $1 \mathrm{mg}$ & $1 \mathrm{mg}$ & $0 \mathrm{mg}$ & $0 \mathrm{mg}$ & $0 \mathrm{mg}$ & $0 \mathrm{mg}$ & $0 \mathrm{mg}$ & $0 \mathrm{mg}$ \\
\hline 7 & $0 \mathrm{mg}$ & $0 \mathrm{mg}$ & $0 \mathrm{mg}$ & $0 \mathrm{mg}$ & $0 \mathrm{mg}$ & $0 \mathrm{mg}$ & $0 \mathrm{mg}$ & $0 \mathrm{mg}$ & $0 \mathrm{mg}$ \\
\hline 8 & $10 \mathrm{mg}$ & $9 \mathrm{mg}$ & $7 \mathrm{mg}$ & $6 \mathrm{mg}$ & $6 \mathrm{mg}$ & $6 \mathrm{mg}$ & $5 \mathrm{mg}$ & $3 \mathrm{mg}$ & $0.5 \mathrm{mg}$ \\
\hline 9 & $5 \mathrm{mg}$ & $5 \mathrm{mg}$ & $4 \mathrm{mg}$ & $3 \mathrm{mg}$ & $3 \mathrm{mg}$ & $3 \mathrm{mg}$ & $3 \mathrm{mg}$ & $0 \mathrm{mg}$ & $0 \mathrm{mg}$ \\
\hline 10 & 15 mg & $10 \mathrm{mg}$ & $5 \mathrm{mg}$ & $35 \mathrm{mg}$ & $20 \mathrm{mg}$ & $15 \mathrm{mg}$ & $7.5 \mathrm{mg}$ & $5 \mathrm{mg}$ & $3 \mathrm{mg}$ \\
\hline 11 & $8 \mathrm{mg}$ & $8 \mathrm{mg}$ & $7 \mathrm{mg}$ & $7 \mathrm{mg}$ & $7 \mathrm{mg}$ & $7 \mathrm{mg}$ & $5 \mathrm{mg}$ & $5 \mathrm{mg}$ & $2 \mathrm{mg}$ \\
\hline 12 & $20 \mathrm{mg}$ & $15 \mathrm{mg}$ & $10 \mathrm{mg}$ & $10 \mathrm{mg}$ & $10 \mathrm{mg}$ & $10 \mathrm{mg}$ & $7 \mathrm{mg}$ & $5 \mathrm{mg}$ & $2 \mathrm{mg}$ \\
\hline 13 & $10 \mathrm{mg}$ & $10 \mathrm{mg}$ & $10 \mathrm{mg}$ & $10 \mathrm{mg}$ & $10 \mathrm{mg}$ & 10 mg & $8 \mathrm{mg}$ & $6 \mathrm{mg}$ & $5 \mathrm{mg}$ \\
\hline 14 & $5 \mathrm{mg}$ & $5 \mathrm{mg}$ & $5 \mathrm{mg}$ & $5 \mathrm{mg}$ & $5 \mathrm{mg}$ & $5 \mathrm{mg}$ & $5 \mathrm{mg}$ & $3 \mathrm{mg}$ & $3 \mathrm{mg}$ \\
\hline 15 & $20 \mathrm{mg}$ & $15 \mathrm{mg}$ & $8 \mathrm{mg}$ & $7 \mathrm{mg}$ & $7 \mathrm{mg}$ & $7 \mathrm{mg}$ & $5 \mathrm{mg}$ & $4 \mathrm{mg}$ & $3 \mathrm{mg}$ \\
\hline 16 & $0 \mathrm{mg}$ & $0 \mathrm{mg}$ & $0 \mathrm{mg}$ & $0 \mathrm{mg}$ & $0 \mathrm{mg}$ & $0 \mathrm{mg}$ & $0 \mathrm{mg}$ & $0 \mathrm{mg}$ & $0 \mathrm{mg}$ \\
\hline
\end{tabular}

Table 4 Changes in the concomitant immunosuppressants use before and after the introduction of MPZ

\begin{tabular}{|c|c|c|c|c|c|c|c|c|c|}
\hline \multirow{2}{*}{$\begin{array}{l}\text { Case } \\
\text { No. }\end{array}$} & \multicolumn{4}{|l|}{ Pre-MPZ } & \multicolumn{5}{|l|}{ Post-MPZ } \\
\hline & -12 months & - 11 months & -9 months & -6 months & 0 months & $\begin{array}{l}1 \\
\text { months }\end{array}$ & $\begin{array}{l}3 \\
\text { months }\end{array}$ & $\begin{array}{l}6 \\
\text { months }\end{array}$ & $\begin{array}{l}12 \\
\text { months }\end{array}$ \\
\hline 1 & MTX 8 mg & MTX 8 mg & None & None & None & None & None & None & None \\
\hline 2 & $\begin{array}{l}\text { MTX } 8 \mathrm{mg}+\mathrm{AZ} \\
125 \mathrm{mg}\end{array}$ & $\begin{array}{l}\text { MTX } 8 \mathrm{mg}+\mathrm{AZ} \\
125 \mathrm{mg}\end{array}$ & $\begin{array}{l}\text { MTX } 8 \mathrm{mg}+\mathrm{AZ} \\
125 \mathrm{mg}\end{array}$ & $\begin{array}{l}\text { MTX } 8 \mathrm{mg}+\mathrm{AZ} \\
125 \mathrm{mg}\end{array}$ & $\begin{array}{l}\text { MTX } 8 \mathrm{mg}+\mathrm{AZ} \\
125 \mathrm{mg}\end{array}$ & $\begin{array}{l}\mathrm{AZ125} \\
\mathrm{mg}\end{array}$ & $\begin{array}{l}\mathrm{AZ125} \\
\mathrm{mg}\end{array}$ & $\begin{array}{l}\mathrm{AZ} 125 \\
\mathrm{mg}\end{array}$ & $\begin{array}{l}\text { AZ100 } \\
\text { mg }\end{array}$ \\
\hline 3 & AZ50 mg & AZ50 mg & AZ $50 \mathrm{mg}$ & AZ 50 mg & AZ $50 \mathrm{mg}$ & $\begin{array}{l}\text { AZ } 50 \\
m g\end{array}$ & $\begin{array}{l}\text { AZ } 50 \\
m g\end{array}$ & $\begin{array}{l}\text { AZ } 50 \\
m g\end{array}$ & $\begin{array}{l}\text { AZ } 50 \\
m g\end{array}$ \\
\hline 4 & None & None & AZ $50 \mathrm{mg}$ & None & None & None & None & $\begin{array}{l}\text { MTX } 8 \\
\text { mg }\end{array}$ & $\begin{array}{l}\text { MTX } 8 \\
\text { mg }\end{array}$ \\
\hline 5 & $\begin{array}{l}\text { MTX } 6 \mathrm{mg}+\mathrm{AZ} \\
50 \mathrm{mg}\end{array}$ & $\begin{array}{l}\text { MTX } 6 \mathrm{mg}+\mathrm{AZ} \\
50 \mathrm{mg}\end{array}$ & $\begin{array}{l}\text { MTX } 6 \mathrm{mg}+\mathrm{AZ} \\
50 \mathrm{mg}\end{array}$ & $\begin{array}{l}\text { MTX } 6 \mathrm{mg}+\mathrm{AZ} \\
50 \mathrm{mg}\end{array}$ & $\begin{array}{l}\text { MTX } 6 \mathrm{mg}+\mathrm{AZ} \\
50 \mathrm{mg}\end{array}$ & $\begin{array}{l}\text { AZ } 50 \\
\mathrm{mg}\end{array}$ & $\begin{array}{l}\text { AZ } 50 \\
\mathrm{mg}\end{array}$ & $\begin{array}{l}\text { AZ } 50 \\
m g\end{array}$ & $\begin{array}{l}\text { AZ } 50 \\
m g\end{array}$ \\
\hline 6 & MTX 16 mg & MTX 16 mg & MTX $16 \mathrm{mg}$ & MTX 16 mg & MTX 16 mg & $\begin{array}{l}\text { MTX } 16 \\
\text { mg }\end{array}$ & $\begin{array}{l}\text { MTX } 10 \\
\text { mg }\end{array}$ & $\begin{array}{l}\text { MTX } 4 \\
\text { mg }\end{array}$ & None \\
\hline 7 & None & None & None & None & None & None & None & None & None \\
\hline 8 & MTX 12 mg & MTX $12 \mathrm{mg}$ & MTX 12 mg & MTX 12 mg & MTX 12 mg & None & None & None & None \\
\hline 9 & AZ 50 mg & AZ 50 mg & AZ 50 mg & AZ 50 mg & AZ $50 \mathrm{mg}$ & None & None & None & None \\
\hline 10 & None & None & IVCY & None & None & None & None & None & None \\
\hline 11 & TAC 3 mg & TAC 3 mg & TAC 3 mg & TAC $3 \mathrm{mg}$ & TAC $3 \mathrm{mg}$ & None & None & None & None \\
\hline 12 & None & None & None & None & None & None & None & None & None \\
\hline 13 & AZ 50 mg & AZ 50 mg & AZ 50 mg & AZ 50 mg & AZ 50 mg & $\begin{array}{l}\text { AZ } 50 \\
\mathrm{mg}\end{array}$ & $\begin{array}{l}\text { AZ } 50 \\
\mathrm{mg}\end{array}$ & $\begin{array}{l}\text { AZ } 50 \\
\mathrm{mg}\end{array}$ & $\begin{array}{l}\text { AZ } 50 \\
\mathrm{mg}\end{array}$ \\
\hline 14 & None & None & None & None & None & None & None & None & None \\
\hline 15 & AZ $100 \mathrm{mg}$ & AZ 100 mg & AZ 100 mg & AZ $100 \mathrm{mg}$ & AZ $100 \mathrm{mg}$ & None & None & None & None \\
\hline 16 & None & None & None & None & None & None & None & None & None \\
\hline
\end{tabular}


Table 5 Adverse events before and after introduction of MPZ

\begin{tabular}{|c|c|c|}
\hline $\begin{array}{l}\text { Case } \\
\text { No. }\end{array}$ & Pre-MPZ & Post-MPZ \\
\hline 1 & $\begin{array}{l}\text { Bacterial pneumonia } \\
\text { (hospitalization) }\end{array}$ & $\begin{array}{l}\text { Bacterial pneumonia } \\
\text { (hospitalization) } \\
\text { Bacterial species: Moraxella } \\
\text { catarrhalis }\end{array}$ \\
\hline 2 & None & None \\
\hline 3 & None & None \\
\hline 4 & Drug-induced liver injury & None \\
\hline 5 & $\begin{array}{l}\text { Sinusitis surgery, bacterial } \\
\text { bronchitis }\end{array}$ & None \\
\hline 6 & $\begin{array}{l}\text { Bacterial bronchitis, infectious } \\
\text { otitis media }\end{array}$ & None \\
\hline 7 & None & None \\
\hline 8 & None & None \\
\hline 9 & None & None \\
\hline 10 & None & None \\
\hline 11 & $\begin{array}{l}\text { Bacterial pneumonia } \\
\text { (hospitalization) }\end{array}$ & $\begin{array}{l}\text { Bacterial pneumonia } \\
\text { (hospitalization) } \\
\text { Bacterial species: Pseudomonas } \\
\text { aeruginosa }\end{array}$ \\
\hline 12 & None & None \\
\hline 13 & $\begin{array}{l}\text { Bacterial pneumonia } \\
\text { (hospitalization) }\end{array}$ & None \\
\hline 14 & Bacterial bronchitis & None \\
\hline 15 & Bacterial pneumonia & Bacterial pneumonia \\
\hline 16 & None & None \\
\hline
\end{tabular}

(Figs. 2a, c, d). MPZ was a useful drug for maintenance therapy that exerted a more consistent effect in controlling disease activity than existing immunosuppressants.

Although the 16 patients included in this study had relatively low eosinophil counts (Table 1), the IL-5 levels before MPZ initiation were significantly higher than those of healthy controls. However, MPZ was effective even in patients whose serum concentration of IL-5 was comparable to that of healthy controls. We believe that these results indicate that MPZ is an effective treatment option in patients with relapsing or refractory EGPA, regardless of IL-5 concentration.

The MPZ retention rate was $100 \%$, and the incidence of infections tended to decrease after MPZ initiation (Table 2). These results confirm the safety of MPZ. In particular, a severe infection that required hospitalization was noted only in two patients with a history of infection, and there was no occurrence of a new serious infection. These results can be considered useful. The reduced incidence of infection might be attributable to the significant reduction in concomitant CS doses and the reduced number of patients using concomitant immunosuppressant after MPZ therapy initiation (Fig. 2d; Tables 3 and 4). The long-term oral administration of CS induces infections and various complications, including osteoporosis, diabetes, hypertension, dyslipidemia, and femoral head necrosis. We did not observe a significant increase in VDI scores nor an increased incidence of complications owing to CS after MPZ therapy initiation. Thus, we demonstrated that MPZ therapy was sufficiently effective in controlling disease activity and prevented adverse events induced by CS and immunosuppressants. In the future, it is important that a long-term investigation is conducted to determine whether long-term MPZ therapy allows the dose reduction or discontinuation of CS without relapse and whether VDI increases.

However, this study has important limitations. For example, this study had limited statistical power owing to the small sample size. Additionally, because the PreMPZ group was set as the control group to compare the effects of MPZ therapy with, the control group might be inadequate. Moreover, few countries recommend subcutaneous MPZ injection at a dose of $300 \mathrm{mg}$ for EGPA, such as Japan. A strength of this study is that although there are some case reports of the use of MPZ at a dose of $300 \mathrm{mg}$ [14] and a case series of the use of MPZ at $100 \mathrm{mg}$ for the treatment of comorbid asthma [15], no studies have investigated the safety and effectiveness of MPZ at $300 \mathrm{mg}$ in real-world clinical practice. To the best of our knowledge, this is the first study to demonstrate the safety and effectiveness of MPZ at $300 \mathrm{mg}$ in a real-world setting.

\section{Abbreviations}

MPZ: Mepolizumab; EGPA: Eosinophilic granulomatosis with polyangiitis;

CS: Corticosteroids; BVAS: Birmingham vasculitis activity score; VDI: Vasculitis damage index; CY: Cyclophosphamide; IVCY: Intravenous cyclophosphamide; AZ: Azathioprine; MTX: Methotrexate; CSA: Cyclosporine; TAC: Tacrolimus; IVIG: Intravenous immunoglobulin; Pre-MPZ: 1-Year period before initiating MPZ therapy; Post-MPZ: 1-Year period after initiating MPZ

\section{Supplementary Information}

Supplementary information accompanies this paper at https://doi.org/10. 1186/s13075-021-02462-6.

Additional file 1: Supplementary Table 1. Clinical manifestations, Japanese Ministry of Health, Labor and Welfare criteria items and classification criteria of the American College of Rheumatology criteria at diagnosis.

Additional file 2: Supplementary Table 2. Baseline characteristic of 16 Patients with Eosinophilic Granulomatosis with Polyangiitis.

Additional file 3: Supplementary Fig. 1. Serum IL-5 concentration of 16 Patients with EGPA before initiating MPZ and health controls $(H C$ group). $P$ values were determined by Mann-Whitney's $U$ test. $P^{*}<0.01$ : EGPA group $(n=16)$ vs. HC $(n=6)$.

\section{Acknowledgements}

The authors thank the study participants, without whom this study would never have been accomplished as well as the investigators for their participation in the study, especially those in Kitakyushu General Hospital, Tobata General Hospital, Saiseikai Shimonoseki General Hospital, Fukuoka Yutaka Central Hospital, Nakama Municipal Hospital, and Steel Memorial Yahata Hospital. 


\section{Authors' contributions}

$\mathrm{MU}$ contributed to the study design, overall review, writing of the manuscript, and the other authors were involved in the performance of the study and review of the manuscript. YT, MI, KN, SI, and SN participated in the study design and coordination. All authors read and approved the final manuscript.

\section{Funding}

No specific funding was received from any bodies in the public, commercial, or not-for-profit sectors to carry out the work described in this article.

\section{Availability of data and materials}

Not applicable.

\section{Declarations}

\section{Ethics approval and consent to participate}

Ethical approval was obtained from the University of Occupational and Environmental Health Japan Ethics Committee following the Helsinki Declaration. This retrospective study was approved by the institutional review board, and the requirement to obtain informed consent was waived.

\section{Consent for publication}

Not applicable.

\section{Competing interests}

Y. Tanaka has received speaking fees and/or honoraria from Daiichi-Sankyo, Astellas, Eli Lilly, Chugai, Sanofi, Abbvie, Pfizer, YL Biologics, Bristol-Myers, Glaxo-Smithkline, UCB, Mitsubishi-Tanabe, Novartis, Eisai, Takeda, Janssen, and Asahi-kasei and has received research grants from Mitsubishi-Tanabe, BristolMyers, Eisai, Chugai, Takeda, Abbvie, Astellas, Daiichi-Sankyo, Ono, MSD, and Taisho-Toyama.

K. Nakano has received speaking fees from Astellas, UCB, Mitsubishi-Tanabe, and Eisai and has received research grants from Mitsubishi-Tanabe, Eisai, and Eli Lilly.

S. Nakayamada received speaking fees and/or honoraria from Bristol-Myers, Sanofi, Abbvie, Eisai, Eli Lilly, Chugai, Asahi-kasei, and Pfizer (less than \$10,000 each) and also research grants from Mitsubishi-Tanabe, Takeda, Novartis, and MSD.

Received: 19 October 2020 Accepted: 22 February 2021

Published online: 16 March 2021

\section{References}

1. Churg J, Strauss L. Allergic granulomatosis, allergic angiitis, and periarteritis nodosa. Am J Pathol. 1951;27:277-301.

2. Jennette JC, Falk RJ, Bacon PA, et al. 2012 Revised International Chapel Hill Consensus Conference nomenclature of vasculitides. Arthritis Rheum. 2013; 65:1-11.

3. Comarmond C, Pagnoux C, et al. Eosinophilic granulomatosis with polyangiitis (Churg-Strauss): clinical characteristics and long-term followup of the 383 patients enrolled in the French Vasculitis Study Group cohort. Arthritis Rheum. 2013;65:270-81.

4. Saku A, Furuta S, et al. Long-term outcomes of 188 Japanese patients with eosinophilic granulomatosis with polyangiitis. J Rheumatol. 2018;45:1159-66.

5. Durel CA, Berthiller J, et al. Long-term follow-up of a multicenter cohort of 101 patients with eosinophilic granulomatosis with polyangiitis (EGPA). Arthritis Care Res. 2016:68:374-87.

6. Wechsler ME, Akuthota P, et al. Mepolizumab or placebo for eosin- ophilic granulomatosis with polyangiitis. N Engl J Med. 2017;376:1921-32.

7. Groh M, Pagnoux C, Baldini C, et al. Eosinophilic Granulomatosis with Polyangiitis (Churg-Strauss) (EGPA) Consensus Task Force recommendations for evaluation and management. Eur J Intern Med. 2015;26:545-53.

8. Yates $M$, Watts RA, et al. EULAR/ERAEDTA recommendations for the management of ANCA-associated vasculitis. Ann Rheum Dis. 2016;75:1583-94.

9. Masi AT, Hunder GG, et al. The American college of rheumatology 1990 criteria for the classification of Churg-Strauss syndrome (allergic granulomatosis and angiitis). Arthritis Rheum. 1990;33:1094-100.

10. Mukhtyar C, et al. Modification and validation of the Birmingham Vasculitis Activity Score (version 3). Ann Rheum Dis. 2009;68(12):1827-32.
11. Flissmann $\mathrm{O}$, Bacon $\mathrm{P}$, et al. Development of comprehensive disease assessment in systemic vasculitis. Ann Rheum Dis. 2007;66(3):283-92.

12. Exley $A R$, et al. Development and initialvalidation of thee vasculitis damage index for standardized clinical assessment of damage in the systemic vasculitoides. Arthritis Rheum. 1997;40:371-180.

13. Puéhal $X$, Pagnoux $C$, et al. Adding azathioprine to remission-induction glucocorticoids for eosinophilic granulomatosis with polyangiitis , microscopic polyangiitis, or polyarteritis nodosa without poor prognosis factors. Arthritis Rheumatol. 2017:69:2175-86.

14. Nara M, Saito $M$, et al. A pediatric case of relapsing eosinophilic granulomatosis with polyangiitis successfully treated with mepolizumab. Intern Med. 2019 Dec 15;58(24):3583-7.

15. Vultaggio A, Nencini F, et al. Low-dose mepolizumab effectiveness in patients suffering from eosinophilic granulomatosis with polyangiitis. Allergy Asthma Immunol Res. 2020;12(5):885-93.

\section{Publisher's Note}

Springer Nature remains neutral with regard to jurisdictional claims in published maps and institutional affiliations.
Ready to submit your research? Choose BMC and benefit from:

- fast, convenient online submission

- thorough peer review by experienced researchers in your field

- rapid publication on acceptance

- support for research data, including large and complex data types

- gold Open Access which fosters wider collaboration and increased citations

- maximum visibility for your research: over $100 \mathrm{M}$ website views per year

At BMC, research is always in progress.

Learn more biomedcentral.com/submissions 